\title{
Heated response to US drought
}

- No signs of break in drought crisis

\section{- Greenhouse effect enters political arena}

Washington

A LITTLE rain fell on portions of the United States last week, but according to the latest forecast from the National Weather Service Climate Analysis Center, the hot dry weather that has been blanketing the country will continue throughout this week, exacerbating the drought conditions plaguing the west, northern plains, midwest and south-east states.

Although the drought is not directly related to the build-up of greenhouse gases which some claim has caused average global temperatures to rise, the juxtaposition of the two events may become more tightly coupled politically than they are scientifically.

Officials at the US Department of Agriculture (USDA) noted warning signs of the possibility of a drought as early as last February. Norton Strommen, chief meteorologist at USDA, says the low level of the snowpack and water supply were signs that, without favourable weather, severe crop damage would result.

When the jetstream failed to move south from Canada in June, hot dry weather prevailed through the critical growing period. Crops such as corn (maize), which is extremely sensitive to heat during anthesis, are being especially hard hit. Half of the Illinois corn crop has already been ruined, and more will be lost if there is no rain.

Ironically, the same warning signs from the snowpack and water level were there in the winter of 1987, but timely spring rains brought record

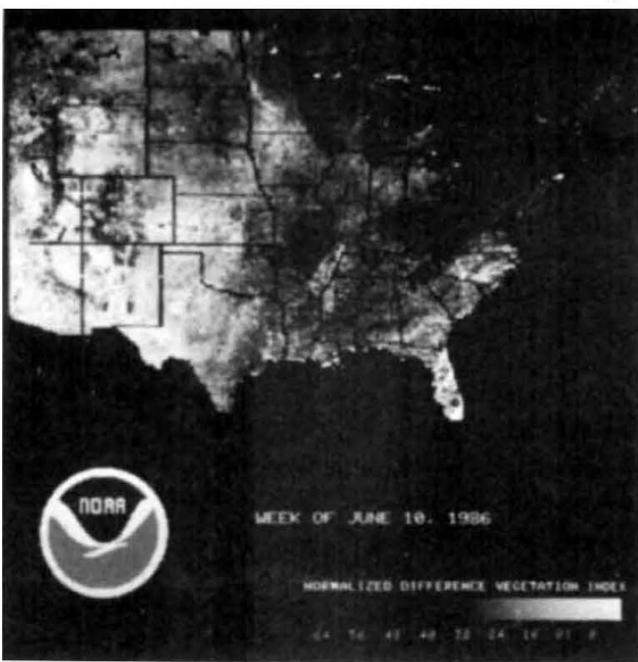

the Palmer Drought Index - a measure of drought conditions - would continue to be at minus 3 for the northern plains, west and mid-west, indicating severe to extreme drought conditions.

Despite a spate of record temperatures, Strommen says the current conditions are not out of line with previous hot summers. He says that although greenhouse warming may be occurring, there is no doubt that the current weather patterns could have occurred without any increased atmospheric $\mathrm{CO}_{2}$.

Strommen believes that increased forest harvesting, coupled with the spread of "civilization" bringing an increase in paved surfaces is a more likely culprit. If solar radiation is not absorbed by evapotranspiration, he says, it will turn into sensible heat.

James Firor, a climatologist at the National Center for Atmospheric Research in Boulder, Colorado, agrees that average temperatures are on the way.

Even if this year's weather conditions are not directly related to greenhouse warming, they may become inextricably linked in public perception. Congress has been holding hearings on this question, and there are daily news reports that catalogue the scope of the problem and attempt to explain its antecedents.

Stephen Schneider, also of NCAR, notes that while bureaucrats move cautiously, insisting on cost-benefit analyses before taking steps to correct a problem, politicians act in response to their reading of public perceptions. As the drought remains in the news, the public belief that it is related to the buildup of greenhouse gasses may grow. By September, as forest fires result from the dry conditions and the presidential campaign moves into full swing, climate control could well become a campaign issue.

The government has meanwhile convened the Presidential Drought Task Force to coordinate the federal response to the crisis. Norman Rosenberg, director of the Climate Resources Program at crop yields last year. It is also true that, if soil moisture had been normal last winter, the hot dry conditions would not have had the same disastrous consequences.

There are clear signs that the drought will get worse before it gets better. According to data from the US Geological Survey, some 60 per cent of 181 index stations around the country report stream flow well below normal for June. By comparison, only 38 per cent of stations were reporting below normal flow in May. Approximately three dozen stations are reporting the lowest water levels on record.

In its latest drought advisory notice issued on 6 July, the Climate Analysis Center long-term forecast predicted that it is not possible to say with certainty that any specific weather pattern is related to the greenhouse effect. But he does believe there is evidence for greater frequency of temperature extremes, such as the one now occurring.

Firor also points to evidence from time series analysis of global climate models that a rise in the average global temperature of 0.5 degrees centigrade will result in increased fluctuations skewed towards warmer temperatures, not a smooth, gradual warming. He says he is well aware that next year, the pattern could change dramatically, with an unusually cool wet summer. "We suspect that even during the ice age there were hot years", he says, but that does not change the fact that warmer

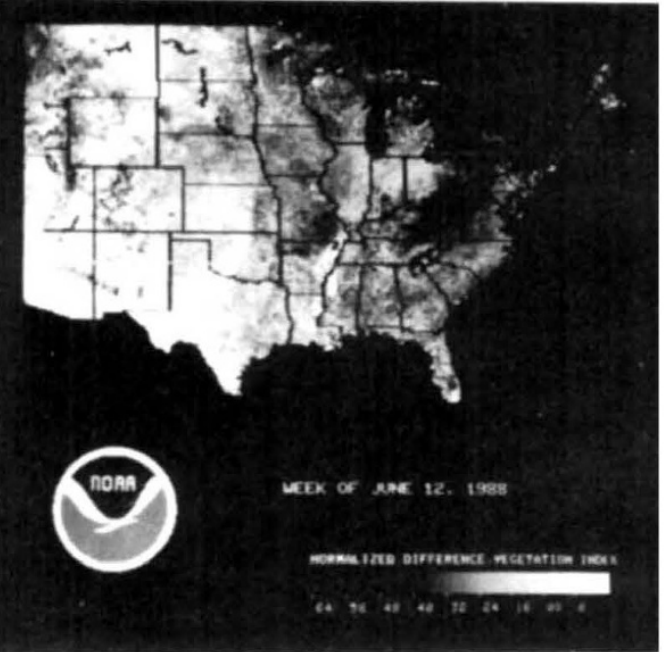

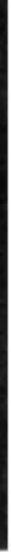

the retreat of vegetation.

Resources for the Future, says that poor responses to droughts in the 1970 s convinced federal officials of the need for better organization, but it is not clear that there is yet the concentrated effort he believes is needed.

Rosenberg's programme is involved in designing strategies that will make US agriculture less vulnerable to extreme weather conditions. Wider use of winter wheat, development of hardier plant species, renewed use of wind breaks, and improved irrigation technology are all strategies that could mitigate damage from future droughts. But Rosenberg warns that the impetus for change often evaporates when rain relieves a drought.

Joseph Palca 